\title{
Rancang Bangun Sistem Informasi Eksekutif Pada Pemerintah Kecamatan Belida Darat Kabupaten Muara Enim
}

\author{
Nurhera Larassati ${ }^{1}$, Novri Hadinata ${ }^{2}$, Siti Sauda $^{3}$ \\ 1,2Information System Departement, Bina Darma University, Palembang, Indonesia \\ ${ }^{3}$ Informatics Departement, Bina Darma University, Palembang, Indonesia \\ Email: yayas.nurhera@gmail.com ${ }^{1}$, novri_hadinata@binadarma.ac.id ${ }^{2}$, siti_sauda@binadarma.ac.id ${ }^{3}$
}

\begin{abstract}
Abstrak
Kecamatan Belida Darat merupakan lembaga pemerintah yang berada di wilayah kabupaten Muara Enim. Kecamatan Belida Darat diresmikan oleh Bupati Muara Enim Ir. H Muzakir Sai Sohar pada tanggal 8 Oktober 2012, merupakan tindak lanjut dari Perda Kabupaten Muara Enim No.1 Tahun 2012 tanggal 20 Juli 2012 merupakan pemekaran dari Kecamatan Lembak. Karena merupakan kecamatan baru, kecamatan ini masih memerlukan banyak sistem yang berguna untuk mempermudah urusan yang ada di kecamatan. Tujuan melakukan penulisan skripsi ini adalah untuk merancang dan membangun suatu sistem informasi eksekutif pada kecamatan Belida Darat dengan berfokus pada laporan monografi. Metode yang digunakan dalam pembuatan sistem ini adalah metode Waterfall. Metode ini merupakan salah satu metode yang banyak digunakan dalam pengembangan perangkat lunak. Hasil implementasi sistem diharapkan dapat mengatasi permasalahan-permasalahan yang dihadapi oleh kecamatan Belida Darat dalam menyajikan laporan untuk eksekutif.
\end{abstract}

Kata Kunci: Sistem Informasi Eksekutif,Belida Darat, Metode Waterfall

\section{PENDAHULUAN}

Perkembangan teknologi informasi tidak hanya berlaku untuk organisasi, dan perusahaan, bahkan saat ini lembaga pemerintahan juga mengembangkan sistem informasi untuk berbagai macam keperluan. Apalagi pada jaman seperti saat ini informasi memang dapat digolongkan sebagai kebutuhan primer. Hal ini dibuktikan dengan kebiasaan masyarakat saat ini yang sangat bergantung dengan teknologi informasi. Sistem informasi eksekutif adalah salah satu keperluan yang diperuntukkan bagi kalangan eksekutif. Apalagi dengan perkembangan teknologi informasi yang sangat pesat dan terus memberi kemudahan dan kenyamanan yang dapat meningkatkan minat masyarakat untuk menikmati berita dan informasi yang ada disekitar, 
sehingga masyarakat dapat memperluas pengetahuan dengan adanya informasi yang tersedia.

Kecamatan Belida Darat adalah salah satu lembaga pelayanan masyarakat yang tinggal di wilayah Belida Darat Kabupaten Muara Enim. Fungsi kecamatan yaitu sebagai pelayanan masyarakat dalam hal pembuatan kartu tanda penduduk atau KTP, pembuatan kartu keluarga, pembayaran PBB, dan pelayanan lainnya yang bersifat kependudukan. Pada Kecamatan Belida Darat terdapat 31 pegawai antara lain 14 diantaranya adalah pegawai negri sipil (PNS), 15 pegawai sebagai TKS dan 2 lainya adalah petugas sat Pol PP.

Pada Kecamatan Belida Darat, laporan yang diberikan kepada camat masih berbentuk laporan monografi yang masih di buat atau di tulis secara manual, laporan Monografi adalah rincian data dan statistik pemerintahan, sumber daya alam, sumber daya manusia, ekonomi, pendidikan, dan kondisi geografis dari suatu wilayah. Pada laporan monografi, laporan yang di lampirkan masih relative banyak dan menumpuk, hal ini menyebabkan pegawai membutuhkan waktu yang relative lama untuk menyusun laporan monografi, sedangkan pihak eksekutif sulit dan butuh waktu untuk membaca dan melihat isi laporan tersebut.

Dari permasalahan di atas maka, dibutuhkan sistem yang mampu mempermudah pegawai untuk membuat laporan dengan cepat dan pihak Eksekutif untuk melihat laporan yang singkat padat dan jelas, dalam hal ini Sistem Informasi Eksekutif yang merupakan sistem yang dapat menyediakan informasi terangkum untuk mendukung pihak Eksekutif dalam pengambilan keputusan. Berdasarkan latar belakang tersebut di atas maka, dibuatlah "Rancang Bangun Sistem Informasi Eksekutif pada Pemerintah Kecamatan Belida Darat Kabupaten Muara Enim".

\section{METODE PENGEMBANGAN}

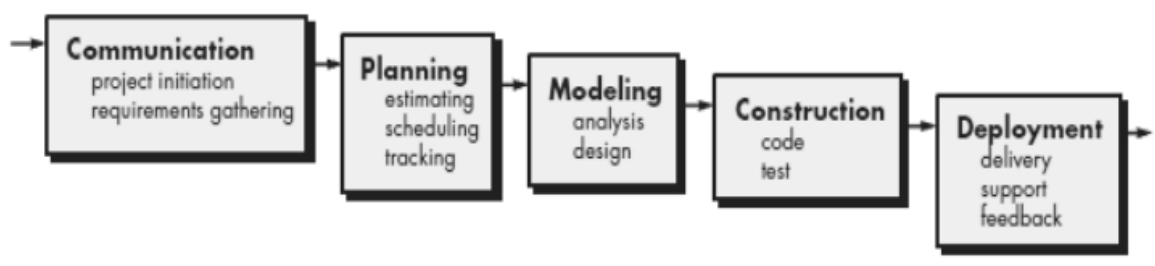

Gambar 1. Fase-Fase Waterfall

Pada penelitian ini metode yang digunakan untuk mengembangkan sistem adalah metode waterfall seperti yang terlihat pada Gambar 1. Menurut 
Pressman (2012) model waterfall adalah model klasik yang bersifat sistematis, berurutan dalam membangun software, yang artinya setiap tahapan dalam pembuatan suatu sistem yang menggunakan metode waterfall dilakukan secara berurutan atau sistematis dan berkelanjutan.

\subsection{Communication}

Ini merupakan tahap awal pada metode waterfall, tahap ini sama dengan tahap analisa, pada tahap ini penulis akan menganalisa permasalahan yang ada yaitu pembuatan laporan-laporan yang ada di kecamatan Belida Darat, pada tahap ini penulis akan mengetahui kebutuhan apa saja yang dibutuhkan user untuk menyusun dan melihat laporan.

\subsection{Planning}

Proses planning merupakan lanjutan dari proses communication (analysis requirement). Tahapan ini akan menghasilkan dokumen user requirement atau bisa dikatakan sebagai data yang berhubungan dengan keinginan user dalam pembuatan software, termasuk rencana yang akan dilakukan. Penelitian ini dilaksanakan di kantor kecamatan Belida Darat kabupaten Muara Enim yang beralamat di desa Tanjung Bunut.

\subsection{Modelling}

Tahap modelling merupakan tahap yang mana proses ini akan menghasilkan dokumen yang berisi tentang kebutuhan atau keinginan user yang sudah diketahui pada tahap analisis sebelum masuk ke tahap pembuatan kode program atau coding. Tahap ini berfokus pada rancangan struktur data, desain software, tampilan (interface), dan detail prosedural. Tahapan ini akan menghasilkan software requirement.

\subsubsection{Analisis Sistem yang Berjalan}

Secara umum pada kecamatan Belida Darat dalam pembuatan laporan dalam hal ini laporan monografi, masih menggunakan cara manual atau tulis tangan, dengan cara yang masih manual, tentu saja hal ini membuat pegawai membutuhkan waktu yang cukup lama untuk menyusun laporan tersebut, sedangkan untuk pihak eksekutif juga akan membutuhkan waktu untuk membaca dan melihat isi laporan tersebut. 


\subsubsection{Analisis Sistem yang Akan Dibuat}

Pada penelitian ini penulis akan mengembangkan sistem informasi eksekutif yang bertujuan untuk mempermudah pihak eksekutif melihat laporan, karena pada sistem ini laporan akan disediakan dalam bentuk grafik, sehingga tidak membutuhkan waktu lama untuk mengerti isi laporan tersebut, penulis merancang sistem informasi eksekutif ini dengan rancangan data alur sebagai berikut:

1. Diagram Usecase

Dibawah ini merupakan Usecase diagram yang terdiri dari 2 pengguna yaitu: Admin dan Eksekutif. Eksekutif adalah camat dan sekcam di Kecamatan Belida Darat.

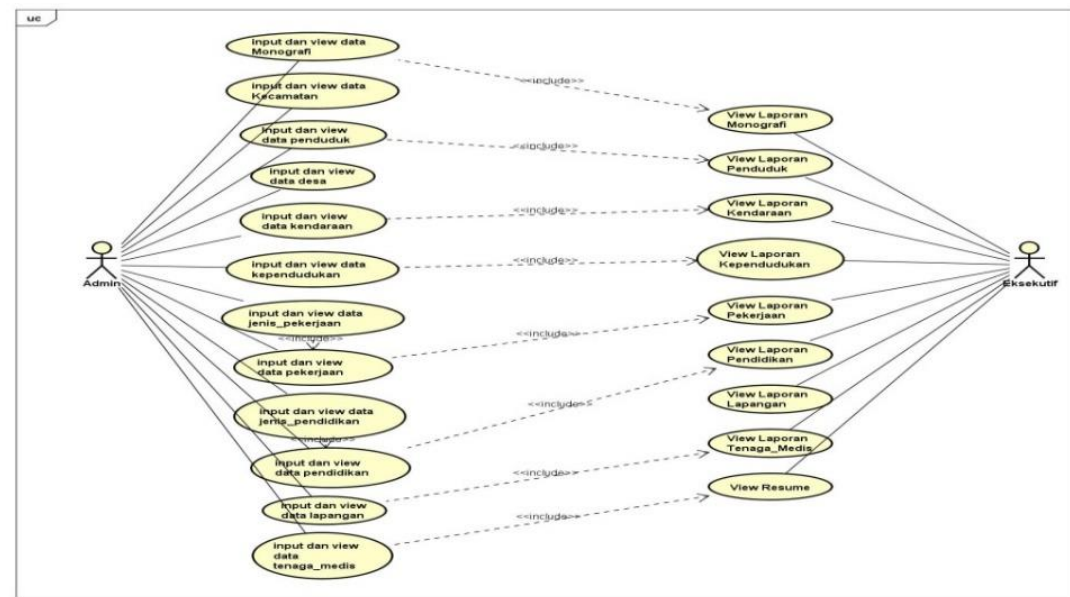

Gambar 2. Diagram Usecase

2. Class Diagram

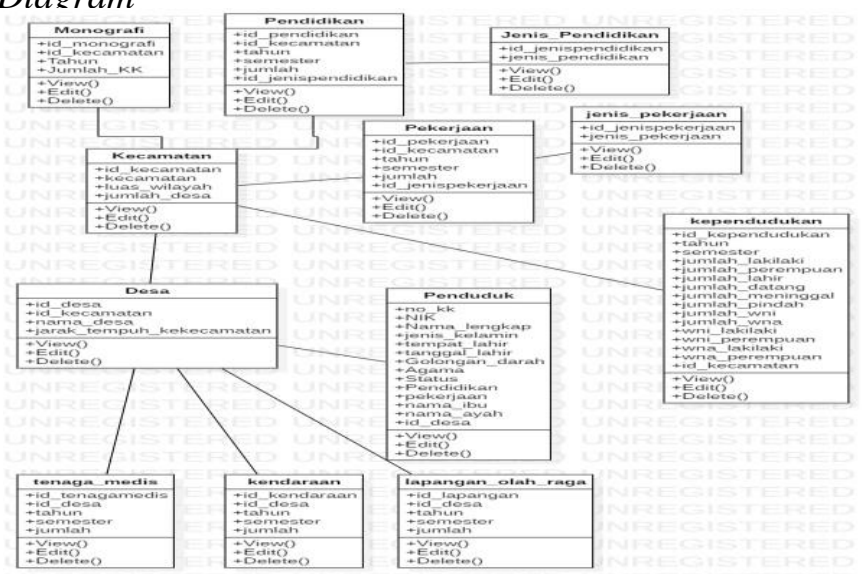

Gambar 3. Class Diagram 


\subsubsection{Rancangan Interface}

\section{Halaman Login}

Halaman login yang berfungsi untuk masuk ke dalam sistem di mana pengguna atau user memasukan username dan password untuk masuk ke system, Login user memiliki hak akses yaitu: Eksekutif dan Admin. Ke-dua user memiliki tampilan halaman login yang sama seperti gambar dibawah ini:

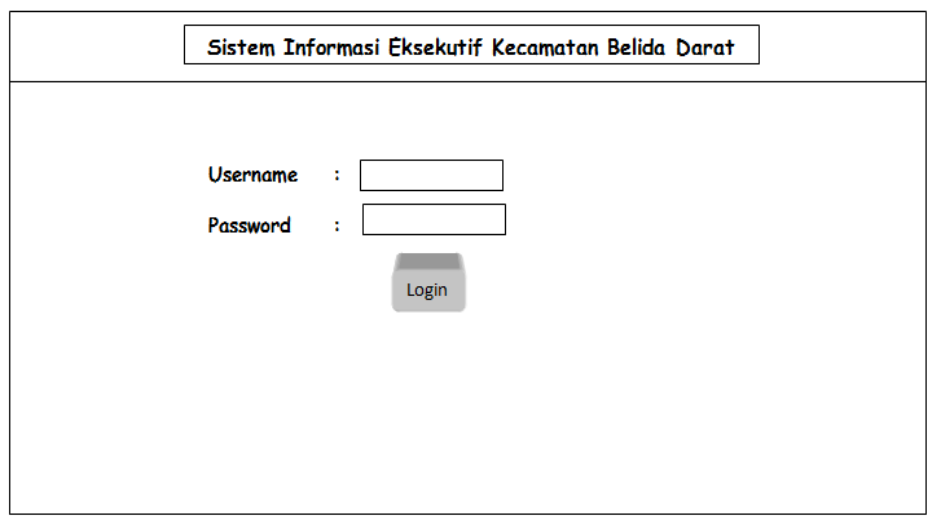

Gambar 4. Halaman Login

\section{Halaman Utama Admin}

Setelah login admin, maka tampilan halaman utama admin akan muncul, menu yang terdapat dalam halaman utama admin berisi informasi tentang nama admin yang sedang beraktivitas di sistem dan menu yang sesuai dengan kebutuhan admin, dengan tampilan seperti dibawah ini :

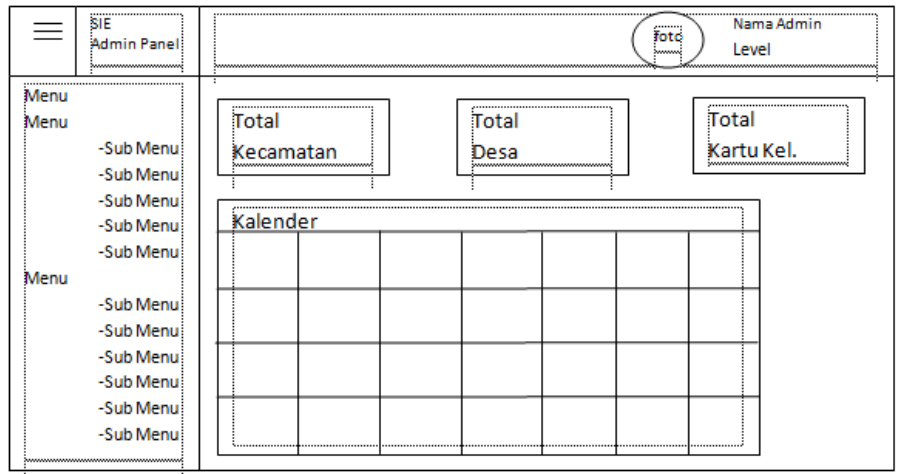

Gambar 5. Halaman Utama Admin 


\section{Halaman Laporan}

Halaman laporan, untuk pengguna dengan level eksekutif, didalam form ini terdapat laporan dalam bentuk grafik dengan tabel di sebelah grafik tersebut, pihak eksekutif tidak diperkenankan untuk mengubah data yang di input oleh admin, eksekutif hanya dapat melihat laporan yang di tampilkan, dengan rancangan tampilan seperti dibawah ini :

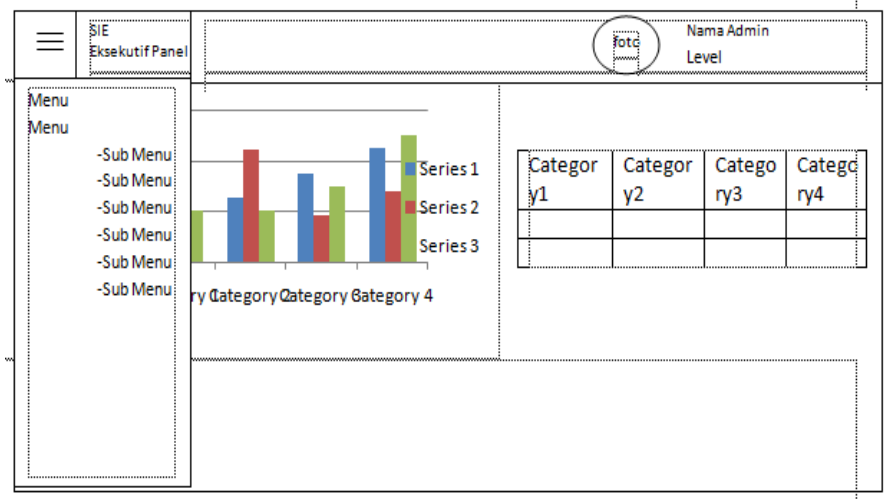

Gambar 6. Halaman Laporan

\subsection{Construction}

Construction yang biasa disebut dengan Coding dan Testing, merupakan proses pembuatan kode dan pengujian program. Coding atau pengkodean merupakan proses penerjemahan dari desain yang telah di buat ke dalam bahasa yang di mengerti oleh computer sehingga dapat menjadi sebuah sistem, pada kasus ini penulis memilih bahasa pemrograman PHP. Sedangkan Testing atau pengujian bertujuan untuk mengetahui dan menemukan kesalahan-kesalahan pada sistem yang kemudian akan diperbaiki. Pada tahap ini penggunaan komputer akan dimaksimalkan karena tahap ini merupakan tahapan sebenarnya dalam pengerjaan suatu sistem.

\subsection{Deployment}

Tahap deployment dilakukan setelah tahap pembuatan kode selesai, Tahap ini adalah tahap yang paling akhir dari pembuatan system setelah melakukan analisis di kecamatan Belida Darat, membuat desain sesuai kebutuhan user, dan pembuatan kode program sesuai dengan desain maka, sistem yang telah selesai di buat akan digunakan oleh user yang ada di kecamatan Belida Darat. Kemudian sistem yang telah dibuat harus dilakukan pemeliharaan secara berkala. 


\section{HASIL DAN PEMBAHASAN}

Setelah melakukan tahapan-tahapan pengembangan sistem menggunakan metode waterfall yang telah diuraikan pada bab-bab sebelumnya maka, yang dihasilkan berupa rancangan sistem ke situasi yang real tentang sistem informasi eksekutif pada pemerintah Kecamatan Belida Darat berbasis website, dengan adanya sistem eksekutif ini dapat membantu pihak eksekutif untuk melihat laporan yang dijadikan sebagai alat pendukung dalam pengambilan keputusan.

Hasil dari penelitian ini dituangkan dalam bentuk website yang akan dijalankan melalui jaringan internet yang menghasilkan suatu sistem yang akan mempermudah pihak eksekutif. Selanjutnya akan dijelaskan tentang fungsi menu dan submenu yang ada di sistem yang telah dibuat, dengan menampilkan interface dari fungsi-fungsi yang ada di sistem tersebut.

\subsection{Halaman Login}

Pada halaman login digunakan untuk mengakses aplikasi dengan cara memasukan Username dan memasukan Password. Akses login bisa dilakukan oleh Eksekutif, Operasional dan Admin dapat mengakses halaman berdasarkan kebutuhan masing-masing user. Berikut ini merupakan gambar dari halaman login:

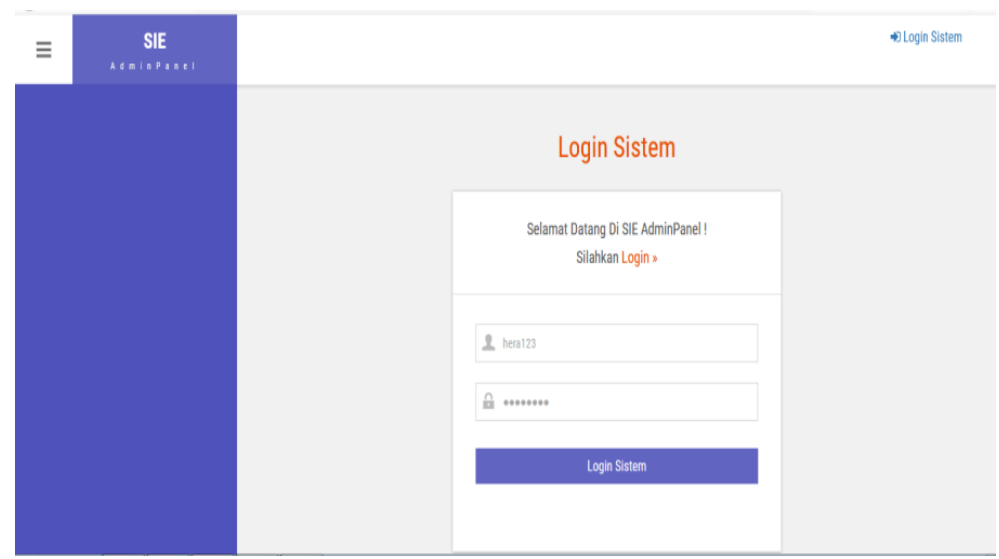

Gambar 7. Halaman Login

\subsection{Halaman Utama Admin}

Halaman Beranda merupakan tampilan awal saat masuk kedalam aplikasi setelah melakuan login, tampilan beranda menu-menu untuk mengelola data. 
http://journal.jis-institute.org/index.php/jpsii/index

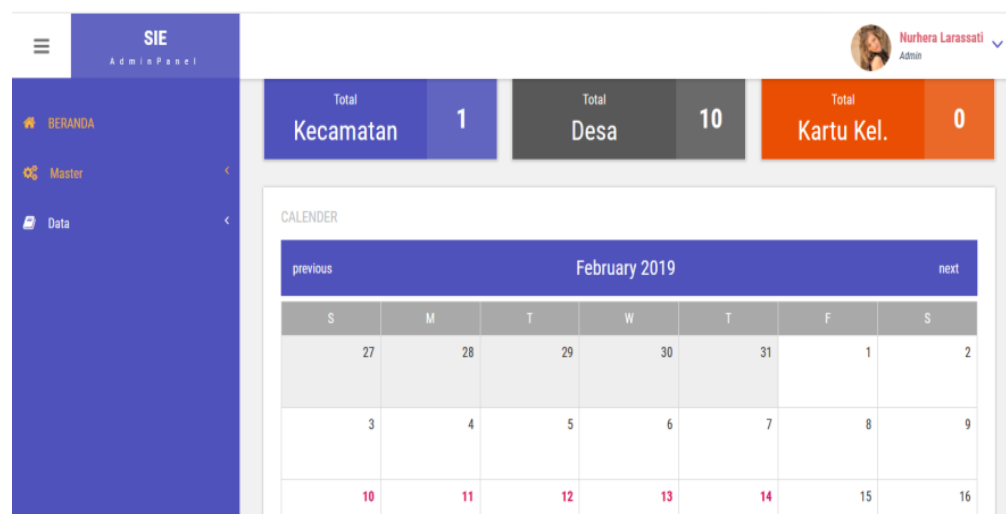

Gambar 8. Halaman Utama Admin

\subsection{Halaman Tambah User}

Halaman ini berguna untuk menambah dan mengubah data user apabila ada perubahan, dengan tampilan seperti dibawah ini:

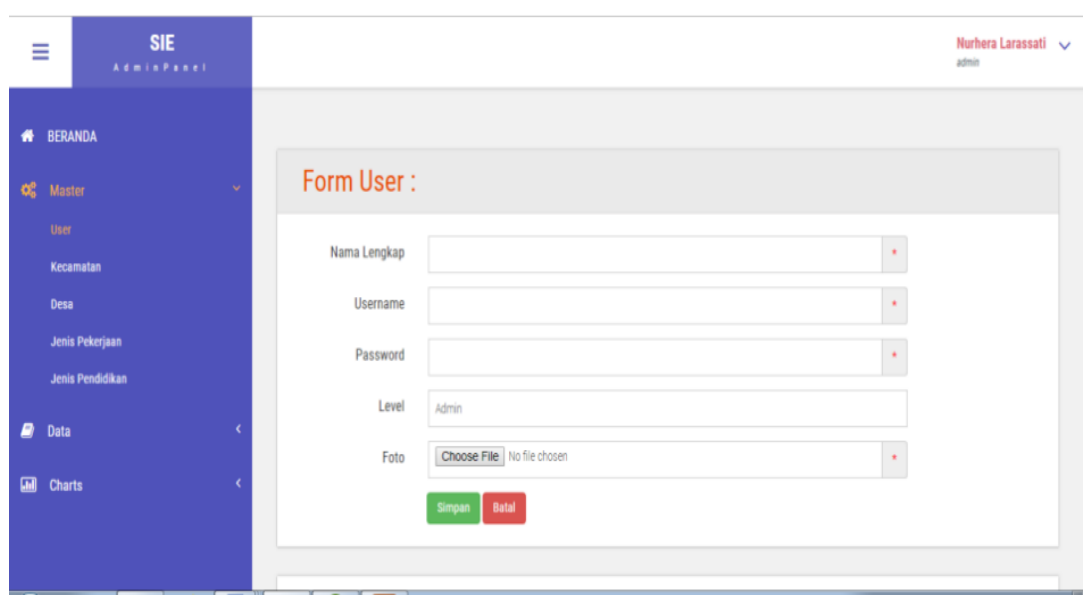

Gambar 9. Halaman Tambah User

\subsection{Halaman Laporan}

Halaman ini berisi tentang grafik dari laporan yang di inginkan dengan memilih menu yang tersedia di sebelah kiri, dengan tampilan seperti dibawah ini: 
http://journal.jis-institute.org/index.php/jpsii/index

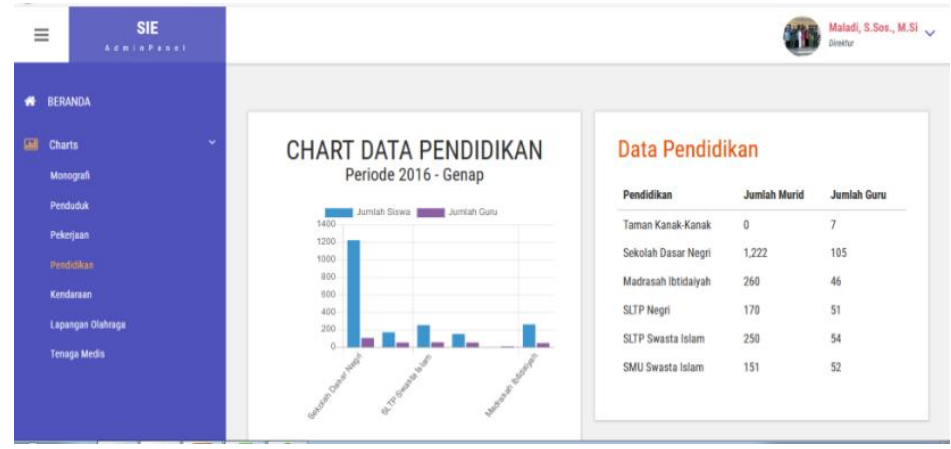

Gambar 10. Laporan

\section{KESIMPULAN}

Kesimpulan dari penelitian yang telah di lakukan yaitu: Dengan adanya aplikasi Sistem Informasi Eksekutif Pada Pemerintah Kecamatan Belida Darat pihak eksekutif dapat lebih mudah dalam melihat perbandingan laporan antar semester sebagai acuan untuk pendukung dalam pengambilan suatu keputusan.

\section{DAFTAR PUSTAKA}

[1] Ardi Fahmi. 2010. "Analisa dan Perangcangan Sistem Monografi Kependudukan Pada E-Government Kabupaten Tanggerang”.

[2] Danang Juniarta, Qorita Shinta, Fito Nurhakim. 2013. "Sistem Informasi Pelaporan Monografi Berbasis Web (Studi Kasus pada Kantor Kecamatan Semarang Utara)".

[3] Presti, Wardhani. (2013). "Sistem Informasi Eksekutif Pembelian Pada PT. Adi Citra Sakti”, Skripsi, Universitas Dian Nuswantoro

[4] Priyandari, yusuf, dkk. (2011). "Rekayasa Sistem Informasi Eksekutif Untik bidang Akademik dan Kemahasiswaan di Universitas Sebelas Maret", Jurnal Performa, vol. 10, no.2

[5] Roger S. Pressman, Ph.D. 2012. "Rekayasa Perangkat Lunak".

[6] Sonny Ariyanto Prabowo, Sholiq, Feby Artwodini Muqtadiroh. 2013. "Rancang Bangun Web Informasi Eksekutif pada Pemerintah Kbupaten $X Y Z$ ”. 